\title{
Severe unicuspid aortic valve stenosis: VACTERL association
}

\author{
Mohamad Soud, ${ }^{1}$ Homam Moussa Pacha, ${ }_{1}^{1}$ M Chadi Alraies ${ }^{2}$
}

\begin{abstract}
- Additional material is published online only. To view please visit the journal online (http://dx.doi.org/10.1136 bcr-2017-222146).
\end{abstract}

'Department of Internal Medicine, MedStar Washington Hospital Center, Washington, District of Columbia, USA ${ }^{2}$ Department of Interventional Cardiology, MedStar Washington Hospital Center, Washington, District of Columbia, USA

Correspondence to Dr M Chadi Alraies, alraies@hotmail.com

Accepted 8 September 2017

CrossMark

\begin{tabular}{l} 
To cite: Soud M, \\
Moussa Pacha H, Alraies MC. \\
BMJ Case Rep Published \\
Online First: [please \\
include Day Month Year]. \\
doi:10.1136/bcr-2017- \\
222146 \\
\hline
\end{tabular}

\section{DESCRIPTION}

A 24-year-old man with a known history of horseshoe kidney leading to end-stage renal disease, scoliosis and small ventricular septal defect consistent with VACTERL association, who presented with worsening dyspnoea on exertion. Transthoracic echocardiogram (TTE) showed a unicuspid aortic valve (UAV) with severe aortic stenosis (AS) (valve area of $0.6 \mathrm{~cm}^{2}$ and mean gradient of $44 \mathrm{~mm} \mathrm{Hg}$ ). TTE also showed moderate aortic insufficiency and severely reduced left ventricular systolic function with estimated ejection fraction of $20 \%$. Transoesophageal echocardiography (TEE) confirmed a UAV with single commissure located anteriorly (figure 1A-D; online supplementary video 1 and supplementary video 2) and severe AS (figure 1B, C). In preparation for surgical repair, chest CT angiogram showed dilated ascending aorta measuring $4 \mathrm{~cm}$ with no evidence of aortic dissection. The patient underwent aortic valve replacement surgery with $21 \mathrm{~mm}$ CarboMedics mechanical valve. TEE showed a well-seated prosthesis without evidence of paravalvular leak (figure 1E). The patient had an uneventful recovery and was discharged after close monitoring for 1 week.

$\mathrm{UAV}$ is a rare form of congenital heart disease seen in approximately $0.02 \%$ of patients referred for echocardiographic studies. ${ }^{1}$ It is susceptible to

\section{Learning points}

- Unicuspid aortic valve is a rare congenital heart defect.

- Patients with unicuspid aortic valve presented at early age with aortic valve stenosis or regurgitation.

- Presence of unicuspid aortic valve in young patients should raise concerns for other congenital abnormalities.

early degeneration thus resulting in aortic stenosis with or without regurgitation. Two forms of UAV have been described, the unicommissural variant which is characterised by the presence of a lateral attachment to the aorta with an eccentric orifice and the acommissural form in case of the absence of such attachment and presence of a central orifice. ${ }^{1}$ UAV has been reported to be associated with other cardiac anomalies such as aortic coarctation, ventricular septal defect, patent ductus arteriosus and aortic aneurysm. ${ }^{2}$ VACTERL association is a group of birth defects that affect multiple organ systems and typically defined by the presence of at least three of the following congenital anomalies: vertebral defects, anal atresia, cardiovascular
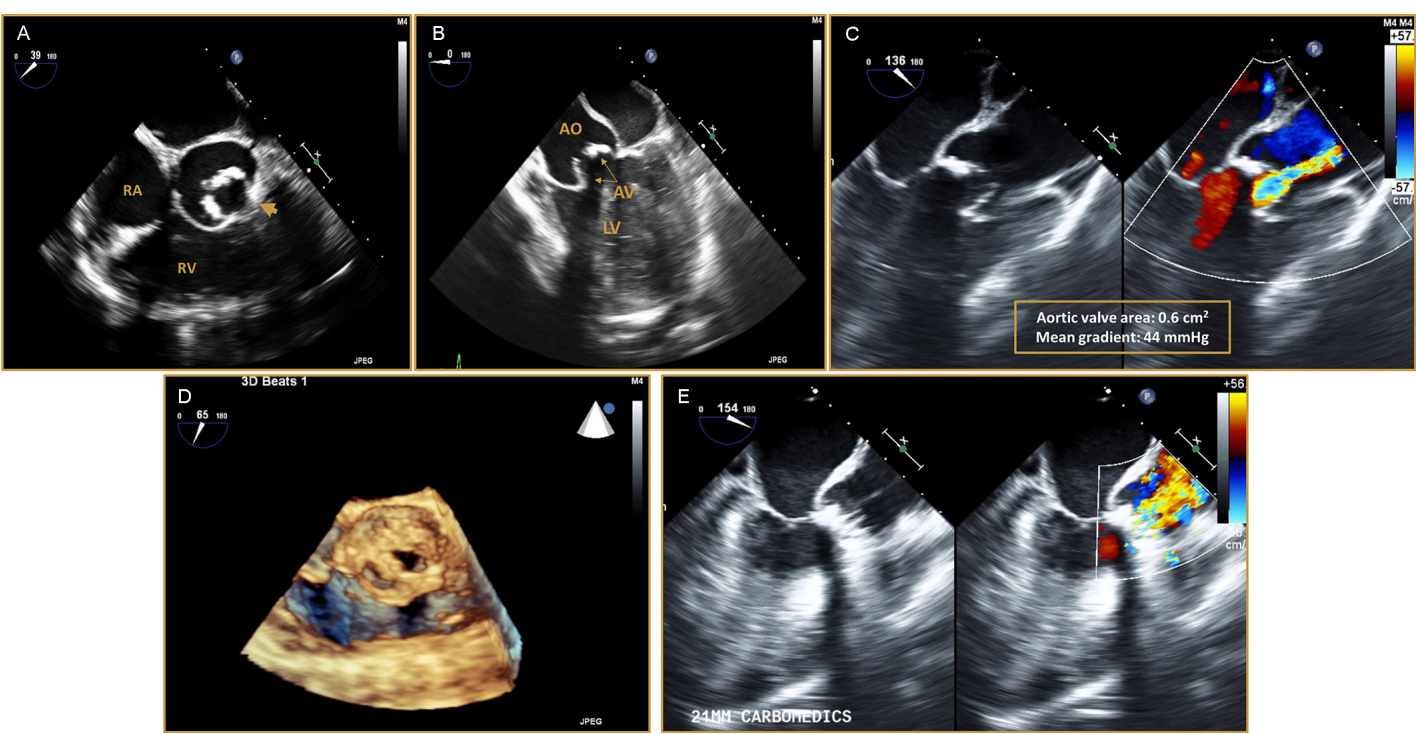

Figure 1 Two-dimensional transoesophageal echocardiography (TEE) images.(A) Short-axis view reveals a unicuspid aortic valve with a single commissure located anteriorly (arrow). (B) Long-axis view shows stenotic aortic valve (AV) and mildly dilated ascending aorta (AO). (C) Long-axis view with Doppler color indicating severe aortic valve stenosis. (D) Three-dimensional TEE image displays a unicommissural unicuspid aortic valve with a poor excursion of the cusp during systole. (E) Two-dimensional long-axis view TEE image showing prosthetic aortic valve with normal Doppler. 
defects, tracheo-oesophageal fistula, renal anomalies or limb abnormalities. ${ }^{3}$ To our knowledge, there is no previous report of unicuspid aortic valve as a part cardiac anomalies in VACTERL association.

Contributors MS and HMP contributed substantially to data interpretation, writing and reviewing the manuscript for important intellectual content. CA is the co-senior authors of this manuscript and had access to all the data, contributed to writing and reviewing the manuscript for important intellectual content.

Competing interests None declared.

Patient consent Obtained.
Provenance and peer review Not commissioned; externally peer reviewed.

(C) BMJ Publishing Group Ltd (unless otherwise stated in the text of the article) 2017. All rights reserved. No commercial use is permitted unless otherwise expressly granted.

\section{REFERENCES}

1 Novaro GM, Mishra M, Griffin BP. Incidence and echocardiographic features of congenital unicuspid aortic valve in an adult population. J Heart Valve Dis 2003:12:674-8

2 Taksande AM. Unicuspid aortic valve in infant. J Cardiovasc Echogr 2015;25:80-2.

3 Solomon BD. Vacterl/Vater association. Orphanet J Rare Dis 2011;6:56.

Copyright 2017 BMJ Publishing Group. All rights reserved. For permission to reuse any of this content visit

http://group.bmj.com/group/rights-licensing/permissions.

BMJ Case Report Fellows may re-use this article for personal use and teaching without any further permission.

Become a Fellow of BMJ Case Reports today and you can:

- Submit as many cases as you like

- Enjoy fast sympathetic peer review and rapid publication of accepted articles

- Access all the published articles

Re-use any of the published material for personal use and teaching without further permission

For information on Institutional Fellowships contact consortiasales@bmjgroup.com

Visit casereports.bmj.com for more articles like this and to become a Fellow 